\title{
PENILAI AGUNAN HAK CIPTA DALAM PERBANKAN DI INDONESIA
}

\section{COLLATERAL APPRAISAL FOR COPYRIGHTS IN BANKING IN INDONESIA}

\author{
Muhammad Yusuf Ibrahim \\ Prodi Ilmu Hukum, Fakultas Hukum, Universitas Abdurachman Saleh Situbondo \\ Email : myibrahim0710028202@gmail.com
}

\begin{abstract}
ABSTRAK
Hak Cipta sebagai suatu benda bergerak tidak berwujud dapat menjadi agunan pada perbankan dalam jaminan fidusia. Pengaturan Hak Cipta dapat dijadikan jaminan fidusia terdapat pada ketentuan pada pasal 16 ayat (3) Undang-Undang Nomor 28 Tahun 2014 tentang Hak Cipta (UUHC). Pasal tersebut memunculkan penafsiran, karena tidak ada pengaturan lebih lanjut menyangkut teknis penilaian agunan di dalam UUHC maupun didalam Undang-Undang Nomor 42 Tahun 1999 Tentang Jaminan Fidusia (UUJF). Pasal 40 ayat (1) UUHC jika dikaitkan terhadap Pasal 16 ayat (3) UUHC menyangkut penilaian agunan memunculkan Penafsiran bahwa tidak semua ciptaan yang dilindungi oleh Hak Cipta dapat dijadikan objek jaminan fidusia. Terjadi kekosongan peraturan pelaksana menyangkut penilaian agunan, maka dalam pelaksanaannya perbankan tidak menerima hak cipta sebagai objek jaminan fidusia. Pasal 16 ayat (3) UUHC tidak dapat diterapkan dikarenakan tidak adanya penilai agunan hak cipta dalam perbankan di Indonesia. Penelitian ini menggunakan penelitian hukum. Preskripsi dari penelitian ini, bahwa harus dibentuk lembaga yang berfungsi sebagai penilai agunan Hak Cipta, sehingga ketentuan bahwa Hak Cipta dapat dijadikan sebagai objek jaminan fidusia dapat terwujud secara nyata.

Kata Kunci : Penilai Agunan, Hak Cipta, Perbankan
\end{abstract}

\begin{abstract}
Copyright as an intangible movable object can become collateral for banks in fiduciary collateral. Copyright arrangements can be used as a fiduciary guarantee contained in the provisions of article 16 paragraph (3) of Law Number 28 of 2014 concerning Copyright (UUHC). The article gave rise to an interpretation, because there was no further regulation concerning the technical assessment of collateral in the UUHC or in Law Number 42 of 1999 Concerning Fiduciary Guarantees (UUJF). Article 40 paragraph (1) of the UUHC if it is related to Article 16 paragraph (3) of the UUHC concerning the assessment of collateral raises the interpretation that not all creations protected by Copyright can be used as fiduciary guarantees. There is a void in implementing regulations concerning collateral valuation, so in practice banks do not accept copyrights as objects of fiduciary security. Article 16 paragraph (3) of the UUHC cannot be applied due to the absence of an appraisal of copyright collateral in banks in Indonesia.

Keyword : Collateral Appraisal, Copyrights, Banking
\end{abstract}


P-ISSN 2580 - 7781

E-ISSN 2615 - 3238

\section{PENDAHULUAN}

Pembangunan perekonomian nasional Indonesia yang berbasis industri ekonomi kreatif membutuhkan jaminan kepastian hukum bagi para pelaku industri kreatif tersebut. Hak cipta merupakan hak kekayaan intelektual di bidang ilmu pengetahuan, seni, dan sastra yang mempunyai peranan strategis dalam mendukung pembangunan bangsa dan memajukan kesejahteraan umum sebagaimana diamanatkan oleh Undang-Undang Dasar Negara Republik Indonesia Tahun 1945. Telah terjadi perubahan sebanyak 5 (lima) kali terhadap Undang-Undang Hak Cipta tersebut, sebagai berikut :

1. Undang-Undang Nomor 6 Tahun 1982,

2. Undang-Undang Nomor 7 Tahun 1987,

3. Undang-Undang Nomor 12 Tahun 1997,

4. Undang-Undang Nomor 19 Tahun 2002,

5. Undang-Undang Nomor 28 Tahun 2014.

Perubahan secepat itu terhadap Undang-Undang Hak Cipta menunjukkan bahwa telah terjadi perkembangan ilmu pengetahuan, teknologi, seni, dan sastra, yang sedemikian pesat di Indonesia sehingga memerlukan peningkatan perlindungan dan jaminan kepastian hukum bagi pencipta, pemegang Hak Cipta, dan pemilik Hak Terkait di Indonesia. Hak Cipta merupakan salah satu bagian dari kekayaan intelektual yang memiliki ruang lingkup objek dilindungi paling luas, karena mencakup ilmu pengetahuan, seni dan sastra (art and literary) yang di dalamnya mencakup pula program komputer.

Penghormatan dan penghargaan terhadap hak cipta di era globalisasi ini menjadi sebuah keharusan bagi negara untuk hadir dalam memberikan perlindungan hukum hak cipta guna mengikuti perkembangan teknologi digital dan industri ekonomi kreatif yang sedang terjadi di masyarakat. Pengaturan perlindungan hukum Hak Cipta yakni Undang-Undang Nomor 28 Tahun 2014 tentang Hak Cipta (selanjutnya disebut UUHC). Saat ini telah terjadi perubahan paradigma dalam memandang Hak Cipta sebagai suatu benda bergerak tidak 
P-ISSN 2580 - 7781

E-ISSN 2615 - 3238

berwujud yang dapat menjadi collateral (agunan) dalam perbankan di Indonesia dalam objek jaminan fidusia.

Dalam pasal 16 ayat (3) UUHC menyatakan bahwa hak cipta dapat dijadikan sebagai objek jaminan fidusia, serta dalam pasal 16 ayat (4) menyatakan pengaturan ketentuan mengenai Hak Cipta sebagai objek jaminan fidusia sebagaimana dimaksud pada ayat (3) dilaksanakan sesuai dengan ketentuan peraturan perundang-undangan.

Dalam bagian kedua tentang ciptaan yang dilindungi pada Pasal 40 ayat (1) UUHC menyatakan bahwa ciptaan yang dilindungi meliputi Ciptaan dalam bidang ilmu pengetahuan, seni, dan sastra, terdiri atas:

a. buku, pamflet, perwajahan karya tulis yang diterbitkan, dan semua hasil karya tulis lainnya;

b. ceramah, kuliah, pidato, dan Ciptaan sejenis lainnya;

c. alat peraga yang dibuat untuk kepentingan pendidikan dan ilmu pengetahuan;

d. lagu dan/atau musik dengan atau tanpa teks;

e. drama, drama musikal, tari, koreografi, pewayangan, dan pantomim;

f. karya seni rupa dalam segala bentuk seperti lukisan, gambar, ukiran, kaligrafi, seni pahat, patung, atau kolase;

g. karya seni terapan;

h. karya arsitektur;

i. peta;

j. karya seni batik atau seni motif lain;

k. karya fotografi;

1. Potret;

m. karya sinematografi;

n. terjemahan, tafsir, saduran, bunga rampai, basis data, adaptasi, aransemen, modifikasi dan karya lain dari hasil transformasi;

o. terjemahan, adaptasi, aransemen, transformasi, atau modifikasi ekspresi budaya tradisional; 
p. kompilasi Ciptaan atau data, baik dalam format yang dapat dibaca dengan Program Komputer maupun media lainnya;

q. kompilasi ekspresi budaya tradisional selama kompilasi tersebut merupakan karya yang asli;

r. permainan video; dan

s. Program Komputer.

Substansi dari Pasal 16 ayat (3) UUHC merupakan bentuk komitmen Negara dalam melakukan terobosan yang sangat besar terhadap perlindungan hukum bagi Hak Cipta karena dengan dapat dijadikannya Hak Cipta sebagai objek jaminan fidusia, berarti Negara telah melakukan pengembangan ekonomi kreatif kepada masyarakat, utamanya para pemuda kreatif yang tidak memiliki aset tetap untuk dapat memiliki modal dalam industri ekonomi kreatif dengan menjaminkan karya ciptanya dalam jaminan fidusia pada perbankan. Pasal 16 ayat (3) UUHC tersebut memunculkan penafsiran, karena tidak ada pengaturan lebih lanjut menyangkut teknis penilaian agunan di dalam UUHC maupun didalam Undang-Undang Nomor 42 Tahun 1999 Tentang Jaminan Fidusia (UUJF). Pasal 40 ayat (1) UUHC jika dikaitkan terhadap Pasal 16 ayat (3) UUHC menyangkut penilaian agunannya memunculkan Penafsiran bahwa tidak semua ciptaan yang dilindungi dalam bidang ilmu pengetahuan, seni, dan sastra tersebut dapat dijadikan objek jaminan fidusia. Terjadi kekosongan peraturan hukum menyangkut penilaian agunan pada pasal 40 ayat (1) UUHC tersebut, maka dalam pelaksanaannya perbankan tidak menerima hak cipta sebagai objek jaminan fidusia. Pasal 16 ayat (3) UUHC tidak dapat diterapkan dikarenakan tidak adanya penilai agunan hak cipta dalam perbankan di Indonesia.

\section{METODE PENELITIAN}

Metode yang digunakan adalah metode penelitian hukum. Kebenaran yang dipakai adalah kebenaran koherensi, yaitu kebenaran untuk mendapatkan sesuatu yang secara aksiologis merupakan nilai atau ketetapan/aturan sebagai referensi untuk yang ditelaah. Dalam hal demikian, bukan fakta empiris yang akan diperoleh, melainkan kesesuaian antara sesuatu yang hendak ditelaah dengan nilai 
P-ISSN 2580 - 7781

E-ISSN 2615 - 3238

atau ketetapan/aturan atau prinsip yang dijadikan referensi. Jika terdapat kesesuaian diantara kedua hal tersebut, itulah yang disebut kebenaran dan apabila sebaliknya, tidak ada kebenaran (falsity). Pendekatan yang digunakan dalam penelitian ini adalah pendekatan perundang-undangan (statute approach), pendekatan komparatif (comparative approach), dan pendekatan konseptual (conceptual approach).

\section{HASIL PENELITIAN DAN PEMBAHASAN}

Dalam kepustakaan Perbankan, dikemukakan secara terminologi "Bank" berasal dari Bahasa Italia "Banco" yang berarti bangku, bangku inilah yang dipergunakan oleh banker untuk melayani kegiatan operasionalnya kepada para nasabah dan Istilah bangku secara resmi dan popular menjadi Bank. Pengertian bank menurut pendapat para ahli, sebagai berikut :

1. A. Abdurachman berpendapat, bahwa perbankan (banking) pada umumnya adalah kegiatan-kegiatan dalam menjual belikan mata uang, surat efek dan instrument-instrumen yang dapat diperdagangkan. Penerimaan deposito, untuk memudahkan penyimpanannya atau untuk mendapatkan bunga, dan/atau pembuatan, pemberian pinjaman-pinjaman dengan atau tanpa barang-barang tanggungan, penggunaan uang yang ditempatkan atau diserahkan untuk disimpan. Pembelian, penjualan, penukaran atau penguasaan atau penahanan alat pembayaran, instrument yang dapat diperdagangkan, atau benda-benda lainnya yang mempunyai nilai moneter secara langsung sebagai suatu kegiatan yang teratur.

2. O.P. Simorangkir berpendapat, bahwa Bank merupakan salah satu badan usaha lembaga keuangan yang bertujuan memberikan kredit dan jasa-jasa. Adapun pemberian kredit itu dilakukan baik dengan modal sendiri atau dengan dana-dana yang dipercayakan oleh pihak ketiga maupun dengan jalan meperedarkan alat-alat pembayaran baru berupa uang giral.

3. Kasmir berpendapat, bahwa bank dikenal sebagai lembaga keuangan yang kegiatan utamanya menerima simpanan giro, tabungan dan deposito, bank juga dikenal sebagai tempat untuk menukar uang, memindahkan uang atau 
P-ISSN 2580 - 7781

E-ISSN 2615 - 3238

menerima segala bentuk pembayaran dan setoran seperti pembayaran listrik, telepon, air, pajak, uang kuliah, dan pembayaran lainnya.

4. Sentosa Sembiring berpendapat, bahwa bank adalah suatu badan usaha yang berbadan hukum yang bergerak dibidang jasa keuangan, yang dapat menghimpun dana dari masyarakat secara langsung dan menyalurkan kembali ke masyarakat melalui pranata hukum perkreditan.

5. Pasal 1 angka 1 Undang-Undang Nomor 10 Tahun 1998 Tentang Perbankan (selanjutnya disebut UUP) menyatakan bahwa Perbankan adalah segala sesuatu yang menyangkut tentang bank, mencakup kelembagaan, kegiatan usaha, serta cara dan proses dalam melaksanakan kegiatan usahanya. Sedangkan pasal 1 angka 2 UUP menyatakan bahwa Bank adalah badan usaha yang menghimpun dana dari masyarakat dalam bentuk simpanan dan menyalurkan kepada masyarakat dalam bentuk kredit dan atau bentukbentuk lainnya dalam rangka meningkatkan taraf hidup rakyat banyak.

Jaminan merupakan terjemahan dari Bahasa Belanda, yaitu Zekerheid atau cautie. Zekerheid atau cautie mencakup secara umum cara-cara kreditur menjamin dipenuhinya tagihannya, disamping pertanggung jawaban umum debitur terhadap barang-barangnya. Sedangkan jaminan dalam terjemahan Bahasa Prancis adalah Guarantee yang bermakna sesuatu yang diberikan kepada kreditur untuk menimbulkan keyakinan pemberi kredit. Didalam Seminar Badan Pembinaan Hukum Nasional yang diselenggarakan di Yogyakarta, dari tanggal 20 sampai dengan 30 juli 1977, disimpulkan bahwa pengertian Jaminan adalah menjamin dipenuhinya kewajiban yang dapat dinilai dengan uang yang timbul dari suatu perikatan hukum. Oleh karena itu, hukum jaminan erat sekali dengan hukun benda.

M. Bahsan berpendapat bahwa jaminan adalah segala sesuatu yang diterima kreditur dan diserahkan debitur untuk menjamin suatu utang piutang dalam masyarakat. SK Direksi Bank Indonesia No. 23/69/KEP/DIR tanggal 28 februari 1991 memberikan pengertian tentang jaminan, yaitu suatu keyakinan kreditur 
P-ISSN 2580 - 7781

E-ISSN 2615 - 3238

(bank) atas kesanggupan debitur untuk melunasi kredit sesuai dengan yang diperjanjikan.

Kitab Undang-Undang Hukum Perdata (KUHPerdata) tidak secara tegas memberikan rumusan tentang jaminan. akan tetapi dengan melihat ketentuan pasal 1131 dan pasal 1132 KUHPerdata, dapat diketahui pengertian tentang jaminan.

Pasal 1131 KUHPerdata menyatakan bahwa, segala kebendaan siberutang (debitur), baik yang bergerak maupun yang tidak bergerak, baik yang sudah ada maupun yang aka nada dikemudian hari, menjadi jaminan suatu segala perikatan debitur tersebut.

Pasal 1132 KUHPerdata menyatakan bahwa, kebendaan tersebut menjadi jaminan Bersama-sama bagi orang yang mengutangkan padanya; pendapatan penjualan benda-benda itu dibagi-bagi menurut keseimbangan, yaitu menurut besar kecilnya piutang masing-masing, kecuali apabila diantara para berpiutang itu ada alasan-alasan yang sah untuk didahulukan.

Menurut Herowati Poesoko, jenis jaminan diterbagi atas 2 (dua) golongan, yaitu jaminan perorangan dan jaminan kebendaan, sebagai berikut :

1. Jaminan Perorangan (borgtoch/Personal Guarantee) adalah jaminan berupa pernyataan kesanggupan yang diberikan oleh seseorang pihak ketiga guna menjamin pemenuhan kewajiban-kewajiban debitur kepada kreditur, apabila debitur yang bersangkutan cidera janji (wanprestasi). Jaminan semacam ini pada dasarnya adalah penanggungan utang yang diatur dalam pasal 1820-1850 BW. Pada perkembangannya, jaminan perorangan juga dipraktekkan oleh perusahaan yang menjamin utang perusahaan lainnya. Bank dalam hal ini sering menerima jaminan serupa, yang disebut Corporate Guarantee.

2. Jaminan Kebendaan (Zakelijke Zekerheid/Security Right in Rem) adalah jaminan berupa harta kekayaan dengan cara pemisahan bagian dari harta kekayaan baik si debitur maupun dari pihak ketiga, guna menjamin pemenuhan kewajiban-kewajiban debitur yang bersangkutan cidera janji (wanprestasi). Jaminan Kebendaan ini menurut sifatnya dibagi menjadi : (1) Jaminan dengan benda berwujud, berupa benda bergerak dan benda 
P-ISSN 2580 - 7781

E-ISSN 2615 - 3238

tidak bergerak; (2) jaminan dengan benda tak berwujud, yang dapat berupa hak tagih (cessie).

M. Khoidin juga membagi jenis jaminan atas 2 (dua) golongan, yaitu jaminan kebendaan dan jaminan perorangan, sebagai berikut :

1. Jaminan Kebendaan adalah jaminan yang mempunyai hubungan langsung dengan benda tertentu milik debitur. Kreditur pemegang jaminan ini mempunyai hak kebendaan (zakelijke recht) dengan ciri-ciri dapat dipertahankan dari siapapun (droit de suite, zaakgevolg) dan senantiasa mengikuti bendanya. Jaminan yang bersifat kebendaan dapat diperalihkan. Pemegang jaminan kebendaan mempunyai kedudukan prioritas, artinya yang lebih dahulu terjadi diutamakan pemenuhannya (kreditur preference). Yang termasuk dalam jenis jaminan ini adalah hak tanggungan atas tanah, hipotik, creditverband, gadai dan fidusia. Jaminan kebendaan ini terdiri dari jaminan kebendaan atas benda berwujud (lijchamelijke, materiele, tangible) yang meliputi benda-benda baik bergerak atau tidak bergerak yang terlihat wujudnya secara nyata. Sedangkan kebendaan atas benda tidak berwujud (onlichamelijke, immaterial, intangible) tertuju pada benda-benda yang tidak terlihat wujudnya secara nyata, namun ada dan diakui oleh undang-undang. Misalnya piutang atau hak tagih, obligasi, dan surat-surat berharga lainnya.

2. Jaminan Perorangan adalah jaminan yang menimbulkan hubungan langsung terhadap perorangan tertentu. Hak yang dimiliki oleh kreditur bersifat relatif yakni berupa hak perorangan (persoonlijke recht). Jaminan ini hanya dapat dipertahankan terhadap debitur (perorangan) tertentu dan terhadap kekayaan debitur umumnya. Sifat dari jaminan perorangan adalah mempunyai asas kesamaan kedudukan diantara para kreditur, sehingga tidak dibedakan mana piutang yang lebih dulu terjadi dengan yang belakangan. Jadi, pemenuhan piutangnya memperhatikan asas kesamaan kedudukan diantara para kreditur (konkurensi). 
P-ISSN $2580-7781$

E-ISSN 2615 - 3238

Agunan merupakan terjemahan kata dalam bahasa Inggris yaitu collateral. Kamus Besar Bahasa Indonesia (KBBI), tidak memberikan perbedaan pengertian jaminan dan agunan, yang sama-sama memiliki arti yaitu tanggungan. Dalam KBBI agunan adalah jaminan; tanggungan. Dalam praktik perbankan, istilah antara jaminan dan agunan dibedakan, yaitu istilah jaminan memiliki makna sebagai kepercayaan atau keyakinan dari bank atas kemampuan atau kesanggupan debitur untuk melaksanakan kewajibannya. Sedangkan istilah agunan memiliki makna sebagai barang atau benda yang dijadikan jaminan untuk melunasi utang debitur.

Pengertian agunan terdapat pada ketentuan pasal 1 angka 23 UndangUndang Nomor 10 Tahun 1998, yang menyatakan bahwa agunan adalah jaminan tambahan yang diserahkan nasabah debitur kepada bank dalam rangka pemberian fasilitas kredit atau pembiayaan berdasarkan prinsip Syariah. Dalam penjelasan pasal 8 ayat (1) UUP “........Untuk memperoleh keyakinan tersebut, sebelum memberikan kredit, bank harus melakukan penilaian yang seksama terhadap watak, kemampuan, modal, agunan, dana prospek usaha dari Nasabah Debitur. Mengingat bahwa agunan sebagai salah satu unsur pemberian kredit, maka apabila berdasarkan unsur-unsur lain telah dapat diperoleh keyakinan atas kemampuan Nasabah Debitur mengembalikan utangnya, agunan hanya dapat berupa barang, proyek, atau hak tagih yang dibiayai dengan kredit yang bersangkutan. Tanah yang kepemilikannya didasarkan pada hukum, dan lain-lain yang sejenis dapat digunakan sebagai agunan. Bank tidak wajib meminta agunan berupa barang yang tidak berkaitan langsung dengan obyek yang dibiayai, yang lazim dikenal dengan agunan tambahan".

Penjelasan pasal 8 ayat (1) UUP diatas menggolongkan agunan menjadi 2 (dua) macam, yaitu : (1) Agunan pokok adalah agunan berupa barang, proyek, atau hak tagih yang dibiayai dengan kredit yang bersangkutan, dan (2) Agunan tambahan adalah agunan berupa barang yang tidak berkaitan langsung dengan obyek yang dibiayai.

Pasal 1 angka 26 Undang-Undang Nomor 21 Tahun 2008 Tentang Perbankan Syariah (UUPS) menyatakan bahwa agunan adalah jaminan tambahan, baik 
P-ISSN 2580 - 7781

E-ISSN 2615 - 3238

berupa benda bergerak maupun benda tidak bergerak yang diserahkan oleh pemilik agunan kepada bank Syariah dan/atau UUS, guna menjamin pelunasan kewajiban nasabah penerima fasilitas.

Collateral Appraisal dalam terjemahan bahasa Indonesia adalah Penilai Agunan. Di Indonesia, Penilai Publik diatur dalam ketentuan Peraturan Menteri Keuangan Republik Indonesia Nomor 101/PMK.01/2014 Tentang Penilai Publik (Permenkeu PP). Dalam Ketentuan Pasal 1 angka (1) Permenkeu PP memberikan pengertian tentang penilaian, yaitu proses pekerjaan untuk memberikan opini tertulis atas nilai ekonomi suatu objek penilaian sesuai dengan Standar Penilaian Indonesia (SPI). Pasal 1 angka (2) menyatakan bahwa Penilai adalah seseorang yang memiliki kompetensi dalam melakukan kegiatan penilaian, yang sekurangkurangnya telah lulus Pendidikan awal penilaian. Sedangkan pada pasal 1 angka 3 memberikan pengertian tentang Penilai Publik, yaitu penilai yang telah memperoleh izin dari Menteri untuk memberikan jasa sebagaimana diatur dalam peraturan Menteri tentang penilai publik.

Pasal 2 Permenkeu PP ini memberikan tujuan dari penilaian yang dilakukan oleh penilai, yaitu sebagai berikut :
a. Transaksi;
b. Pelaporan keuangan sektor privat dan sektor publik;
c. Penjaminan utang;
d. Penerimaan negara dan
e. tujuan penilaian lainnya sesuai SPI.

SPI merupakan kepanjangan dari Standar Penilaian Indonesia yang merupakan sebuah pedoman dasar yang wajib dipatuhi oleh penilai dalam melakukan penilaian. penilaian dilakukan dengan proses penilaian sebagai berikut:
a. Mengidentifikasi dan memahami lingkup penugasan;
b. melakukan pengumpulan, pemilihan dan analisis data;
c. menerapkan pendekatan penilaian; dan
d. menyusun laporan akhir. 
P-ISSN 2580 - 7781

E-ISSN 2615 - 3238

Penilai publik memiliki tugas melakukan penilaian terhadap bidang jasa yang meliputi :

a. Penilaian properti sederhana;

b. Penilaian properti; dan

c. Penilaian bisnis.

Yang dimaksud dengan bidang jasa penilaian properti sederhana adalah sebagai berikut, Pertama, penilaian terhadap tanah kosong untuk permukiman paling luas 5.000 (lima ribu) meter persegi yang diperuntukkan untuk 1 (satu) unit rumah tinggal. Kedua, penilaian terhadap 1 (satu) unit apartemen, rumah tinggal, rumah toko, rumah kantor, atau kios. Ketiga, penilaian terhadap peralatan dan perlengkapan bangunan yang terikat pada apartemen, rumah tinggal, rumah toko, rumah kantor, atau kios. Keempat, penilaian terhadap 1 (satu) unit mesin individual yang digunakan pada rumah tinggal, rumah toko, atau rumah kantor, termasuk pembangkit tenaga listrik (genset) dan pompa air. Kelima, penilaian terhadap 1 (satu) unit alat transportasi dengan klasifikasi mobil penumpang, mobil beban, dan sepeda motor, yang bukan merupakan suatu armada angkutan.

Yang dimaksud dengan bidang jasa penilaian properti adalah sebagai berikut, Pertama, penilaian terhadap tanah beserta kelengkapannya, serta pengembangan lainnya atas tanah. Kedua, penilaian terhadap mesin dan peralatan termasuk instalasinya yang dirangkai dalam satu kesatuan dan/atau berdiri sendiri yang digunakan dalam proses produksi. Ketiga, penilaian terhadap alat transportasi, alat berat, alat komunikasi, alat kesehatan, alat laboraturium dan utilitas, peralatan dan perabotan kantor dan peralatan militer. Keempat, penilaian terhadap perangkat telekomunikasi termasuk peralatan pemancar dan penerima jaringan, satelit, dan stasiun bumi. Kelima, penilaian terhadap pertanian, perkebunan, peternakan, perikanan, dan perhutanan. dan keenam, penilaian terhadap pertambangan.

Sedangkan yang dimaksud dengan bidang jasa penilaian bisnis adalah sebagai berikut, Pertama, penilaian terhadap entitas bisnis. Kedua, penilaian terhadap penyertaan. Ketiga, penilaian terhadap surat berharga termasuk derivasinya. Keempat, penilaian terhadap hak dan kewajiban perusahaan. Kelima, 
P-ISSN 2580 - 7781

E-ISSN 2615 - 3238

penilaian terhadap aset tak berwujud. Keenam, penilaian terhadap kerugian ekonomis yang diakibatkan oleh suatu kegiatan atau peristiwa tertentu untuk mendukung berbagai tindakan korporasi atau atas transaksi material. Ketujuh, penilaian terhadap opini kewajaran. dan Kedelapan, penilaian terhadap instrumen keuangan.

Dalam memberikan jasa penilaiannya, penilai publik mendirikan kantor jasa penilai publik (KJPP). ketentuan pasal 1 angka 6 Permenkeu PP menyatakan bahwa KJPP adalah badan usaha yang telah mendapatkan izin usaha dari Menteri sebagai wadah bagi penilai publik dalam memberikan jasanya. jadi, penilai publik dapat mendirikan KJPP berbentuk perseorangan yang menggunakan nama lengkap penilai publik tersebut, atau menjadi rekan pada KJPP berbentuk persekutuan perdata atau firma dengan menggunakan nama lengkap salah seorang atau lebih rekan yang merupakan penilai publik.

Bank dalam melakukan kegiatan usahanya harus tidak lepas dari ramburambu hukum berupa safe dan sound. Safe memiliki pengertian bahwa kegiatankegiatan yang bersangkutan haruslah tidak boleh membawa resiko yang substansial (substantive risk) kepada bank, jadi, bank tidak boleh melakukan kegiatan yang bersifat spekulatif. Sedangkan sound memiliki pengertian bahwa kegiatan bank tersebut haruslah layak digolongkan sebagai suatu kegiatan bank, jadi, bank tidak boleh berbisnis yang sama sekali tidak ada hubungannya dengan dunia perbankan.

Berdasarkan pasal 8 ayat (1) UUP menyatakan dalam memberikan kredit atau pembiayaan berdasarkan Prinsip Syariah, Bank Umum wajib mempunyai keyakinan berdasarkan analisis yang mendalam atau itikad baik dan kemampuan serta kesanggupan nasabah debitur untuk melunasi utangnya atau mengembalikan pembiayaan dimaksud sesuai dengan yang diperjanjikan. Dalam penjelasan pasal 8 ayat (1) UUP menjelaskan bahwa kredit atau pembiayaan berdasarkan Prinsip Syariah yang diberikan oleh bank mengandung resiko, sehingga dalam pelaksanaannya bank harus memperhatikan asas-asas perkreditan atau pembiayaan berdasarkan Prinsip Syariah yang sehat. Untuk mengurangi resiko tersebut, jaminan pemberian kredit atau pembiayaan berdasarkan Prinsip Syariah 
P-ISSN $2580-7781$

E-ISSN 2615 - 3238

dalam arti keyakinan atas kemampuan dan kesanggupan Nasabah Debitur untuk melunasi kewajibannya sesuai dengan yang diperjanjikan merupakan faktor penting yang harus diperhatikan oleh bank. Untuk memperoleh keyakinan tersebut, sebelum memberikan kredit, bank harus melakukan penilaian yang seksama terhadap watak, kemampuan, modal, agunan, dana prospek usaha dari Nasabah Debitur. Mengingat bahwa agunan sebagai salah satu unsur pemberian kredit, maka apabila berdasarkan unsur-unsur lain telah dapat diperoleh keyakinan atas kemampuan Nasabah Debitur mengembalikan utangnya, agunan hanya dapat berupa barang, proyek, atau hak tagih yang dibiayai dengan kredit yang bersangkutan. Tanah yang kepemilikannya didasarkan pada hukum, dan lain-lain yang sejenis dapat digunakan sebagai agunan. Bank tidak wajib meminta agunan berupa barang yang tidak berkaitan langsung dengan obyek yang dibiayai, yang lazim dikenal dengan agunan tambahan. Disamping itu, bank dalam memberikan kredit atau pembiayaan berdasarkan Prinsip Syariah harus pula memperhatikan hasil Analisis Mengenai Dampak Lingkungan (AMDAL) bagi perusahaan yang berskala besar dan/atau resiko tinggi agar proyek yang dibiayai tetap menjaga kelestarian lingkungan.

Tujuan diberlakukannya prinsip kehati-hatian dan dijabarkan dalam berbagai rambu-rambu kesehatan perbankan adalah tidak lain agar bank selalu dalam keadaan sehat, liquid, solvent, dan profitable. Bilamana bank dalam kondisi sehat, maka menjamin kepercayaan masyarakat terhadap eksistensi bank, karena keberadaan bank sangat bergantung kepada kepercayaan masyarakat. Disamping itu, Otoritas Jasa Keuangan (OJK) sangat berkepentingan terhadap pengaturan dan pengawasan terhadap perbankan termasuk masalah-masalah yang berkaitan dengan pelaksanaan prinsip-prinsip perbankan dan OJK sebagai pengawas bank berkewajiban untuk mengawasi kepatuhan bank dalam menerapkan prinsip kehati-hatian dalam kegiatan usahanya.

Prinsip kehati-hatian ini harus dijalankan oleh bank bukan hanya karena dihubungkan dengan kewajiban bank agar tidak merugikan kepentingan nasabah yang mempercayakan dananya kepada masyarakat, tetapi juga sebagai bagian dari sistem moneter yang menyangkut kepentingan semua anggota masyarakat yang 
P-ISSN 2580 - 7781

E-ISSN 2615 - 3238

bukan hanya nasabah penyimpan dana dari bank itu saja. Dengan demikian, prinsip kehati-hatian ini bertujuan agar bank menjalankan usahanya secara baik dan benar dengan mematuhi ketentuan-ketentuan dan norma-norma hukum yang berlaku dalam dunia perbankan agar bank selalu dalam keadaan sehat sehingga masyarakat semakin mempercayainya yang pada gilirannya akan mewujudkan sistem perbankan yang sehat dan efesien serta berkembang secara wajar dan bermanfaat bagi perkembangan ekonomi nasional.

\section{KESIMPULAN}

Tujuan perlindungan hukum terhadap pencipta yang menghasilkan suatu karya cipta yang mana ciptaan tersebut dihasilkan dari suatu kreatifitas, imajinasi, cipta, rasa dan karsa pencipta tidak dapat terlindungi. Ketiadaan penilai agunan (collateral appraisal) hak cipta dalam perbankan di Indonesia mengakibatkan kepastian hukum dalam pasal 16 ayat (3) tidak dapat diterapkan. Karena tidak memiliki pedoman sebagai dasar hukum dalam memberikan nilai materi hak cipta. Maka keberadaannya sama seperti dengan ketidakberadaannya, karena tidak dapat diterapkan. Karena itu preskripsi dari penelitian ini adalah agar perbankan menciptakan lembaga penilai agunan bagi Hak Cipta, agar jenis-jenis Ciptaan yang telah diatur pada ketentuan pasal 40 ayat 1 UUHC dapat diterapkan.

\section{DAFTAR PUSTAKA}

\section{Buku:}

Abdurachman, 1991, Ensiklopedia Ekonomi Keuangan Perdagangan InggrisIndonesia, Pradnya Paramita: Jakarta.

Herowati Poesoko, 2013, Dinamika Hukum Parate Executie Obyek Hak Tanggungan, Aswaja Pressindo: Yogyakarta.

Kasmir, 2002, Bank dan Lembaga Keuangan Lainnya, Edisi Keenam, PT. RajaGrafindo Persada: Jakarta.

Malayu S.P. Hasibuan, 2004, Dasar-Dasar Perbankan, Cetakan ketiga, Bina Aksara: Jakarta.

Mariam Darus Badrulzaman, 1987, Bab-Bab Tentang Creditverband, Gadai dan Fidusia, Cetakan ke IV, Alumni: Bandung. 
P-ISSN 2580 - 7781

E-ISSN 2615 - 3238

M. Bahsan, 2002, Penilaian Jaminan Kredit Perbankan Indonesia, Rejeki Agung: Jakarta.

M. Khoidin, 2017, Hukum Jaminan (Hak-Hak Jaminan, Hak Tanggungan, dan Eksekusi Hak Tanggungan), Laksbang Yustitia: Surabaya.

O.P. Simorangkir, 1998, Seluk Beluk Bank Komersial, Perbanas: Jakarta.

Peter Mahmud Marzuki, 2016, Penelitian Hukum Edisi Revisi, PrenadaMedia Group: Jakarta.

Sentosa Sembiring, 2012, Hukum Perbankan, Edisi Rivisi, Cetakan Ketiga, Mandar Maju: Bandung.

Trisandini.P.U dan Abd Shomad, 2017, Hukum Perbankan, Kencana: Depok.

Uswatun Hasanah, 2017, Hukum Perbankan, Setara Press: Malang.

\section{Perundang-Undangan}

Undang-Undang Dasar Negara Republik Indonesia 1945.

Kitab Undang-Undang Hukum Perdata.

Undang-Undang Nomor 28 Tahun 2014 tentang Hak Cipta.

Undang-Undang Nomor 42 Tahun 1999 Tentang Jaminan Fidusia.

Peraturan Menteri Keuangan Republik Indonesia Nomor 101/PMK.01/2014 Tentang Penilai Publik. 